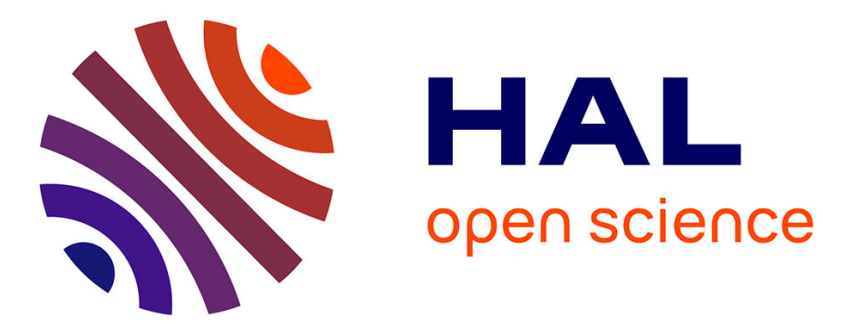

\title{
PLASTIC DEFORMATION OF AMORPHOUS SILICA : MODIFICATION OF THE RING STATISTIC
}

\author{
P. Donnadieu
}

\section{To cite this version:}

P. Donnadieu. PLASTIC DEFORMATION OF AMORPHOUS SILICA: MODIFICATION OF THE RING STATISTIC. Journal de Physique Colloques, 1985, 46 (C9), pp.C9-159-C9-162. 10.1051/jphyscol:1985922 . jpa-00225288

\section{HAL Id: jpa-00225288 https://hal.science/jpa-00225288}

Submitted on 1 Jan 1985

HAL is a multi-disciplinary open access archive for the deposit and dissemination of scientific research documents, whether they are published or not. The documents may come from teaching and research institutions in France or abroad, or from public or private research centers.
L'archive ouverte pluridisciplinaire HAL, est destinée au dépôt et à la diffusion de documents scientifiques de niveau recherche, publiés ou non, émanant des établissements d'enseignement et de recherche français ou étrangers, des laboratoires publics ou privés. 


\section{PLASTIC DEFORMATION OF AMORPHOUS SILICA : MODIFICATION OF THE RING STAT IST IC}

P. Donnadieu

Laboratoire de Physique des Solides, Bât. 510, 91405 Orsay Cedex, France

Résumê - Nous montrons que la déformation plastique de la silice vitreuse en dessous de la température de transition vitreuse est caractérisẻe par une inhomogénéité du fluage. Celle-ci se manifeste par l'apparition de zones anisotropes qui sont examinées en microspectroscopie Raman. Une modification structurale est ainsi mise en évidence.

Abstract - We show that plastic deformation of amorphous silica below the glass transition temperature is characterized by a flow inhomogeneity. This anpears as birefringent zones which are investigated by Raman microspectroscopy. A structural modification is thus put in evidence.

\section{I - INTRODUCTION}

Plastic deformation of amorphous materials below the glass transition is a widely studied topic. Most of the works concern amorṇhous metals and less covalent glasses. One of the main observations in metglass, for instance, is the inhomogeneity of the deformation : any deformation test (bending, traction, compression) induces slip lines $/ 1 /$. This localized slip is often explained by assuming chemical or structural disordering $/ 2 /$ without any experimental evidence of the modification due to plastic deformation. We report some experiments on silica glassthat point out a drastic change of the sample after low temperature deformation and the connected structural modification. To put in evidence this alteration, we use the Raman microspectroscopy. With Raman spectra, we get some information on the modification of the medium range order : the two Raman active "defect" lines $\left(D_{1}: 490 \mathrm{~cm}^{-1}\right.$ and $D_{2}: 605 \mathrm{~cm}^{-1}$ being linked to the concentration of fourfold and threefold rings of $\mathrm{SiO}_{4}$ tetrahedra, according to Galeener's interpretation of the polarized Raman spectra in $\mathrm{v}-\mathrm{SiO}_{2} / 3 /$.

\section{II - EXPERIMENTAL RESULTS}

\section{Plastic}

The flow apparatuses we use allow axial compression tests on small samples (about $(3 \mathrm{~mm})^{3}$ ). We apply stresses up to 2 kbars with a sample temperature going from $1000^{\circ} \mathrm{C}$ to $1400^{\circ} \mathrm{C}$. The flow rate $\varepsilon$ is obtained as a function of the temperature $T$ and the compressive stress $\sigma$.

Above the glass transition temperature $\left(\mathrm{Tg}=1200^{\circ} \mathrm{C}\right)$, we find the well-known Newtonian behavior. Below $\mathrm{Tg}$, the deformation law becomes non-linear $/ 4 /$. Flow! inhemogeneity appears at the same temperature $\left(T \sim 1000^{\circ} \mathrm{C}\right)$. Slip lines have never been observed but the samples exhibit birefringent zones. In order to see them, we cut a deformed sample in thin slices (thickness : $100 \mu \mathrm{m}$ ) ; then, after polishing each face, the thin section is observed in a transmission microscone between crossed polarizers. When the sample has been deformed at a temperature above $\mathrm{Tg}$, it remains isotropic but when the deformation takes place below $\mathrm{Tg}$, numerous birefringent zones appear. The birefringence is roughly measured with a compensator: $\Delta n \sim 10^{-5}$. Photo $n^{\circ} 1, n^{\circ} 2$ and $n^{\circ} 3$ show the same thin section but the direction of the deformation is each time different in every photo : birefringent zones remain obvious. It means that the optical axes are widely distributed, actually most of the zones have optical axes parallel to the stress direction or at $45^{\circ}$ to this direction. 


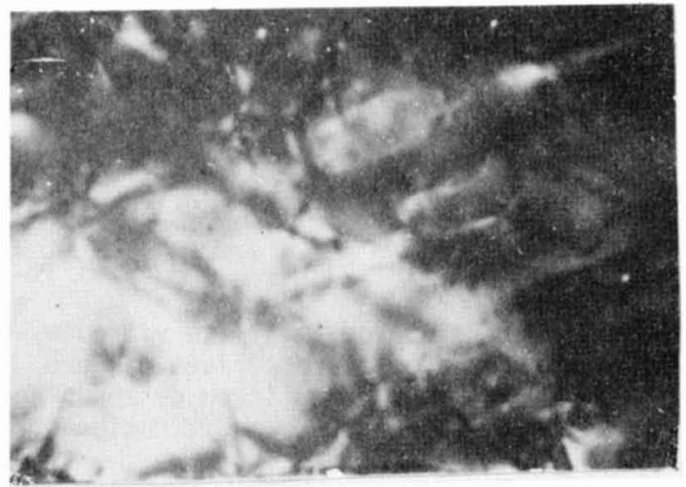

The directions of the polarizers are indicated by the arrow $P$, the stress direction by the arrow $C$.

\section{Photo $n^{\circ} 1$}

The sample thickness is $100 \mu \mathrm{m}$. The spread zones and the crosses are obvious. Their quasi-reqular disposal is more evident on the right side of the photo.
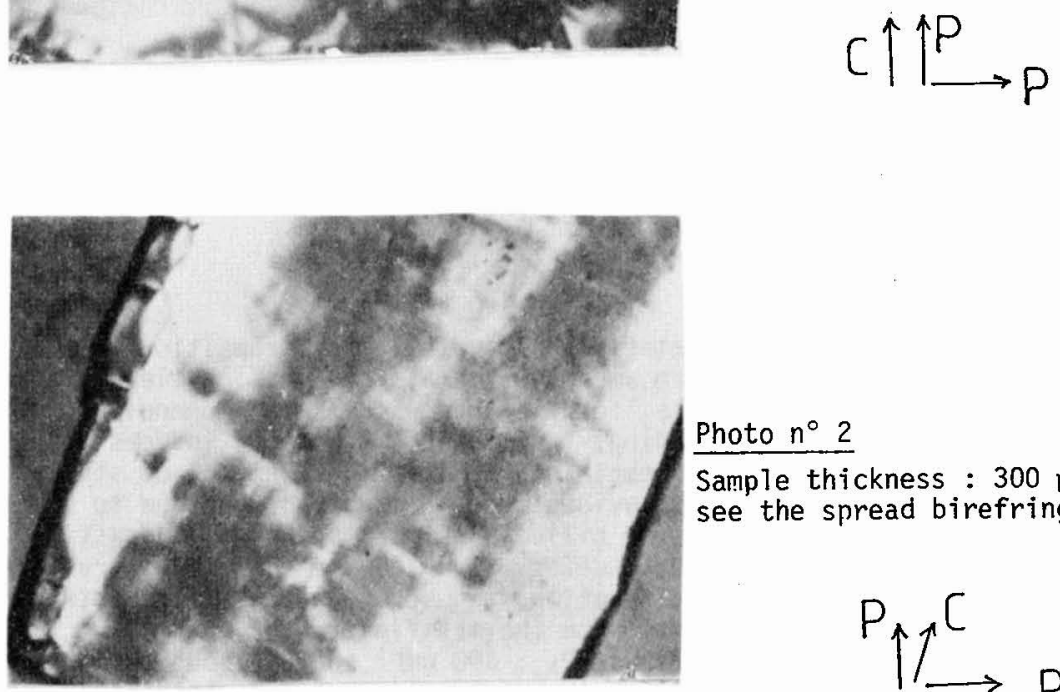

\section{Photo $n^{\circ} 2$}

Sample thickness : $300 \mu \mathrm{m}$. We only see the spread birefringent zones.
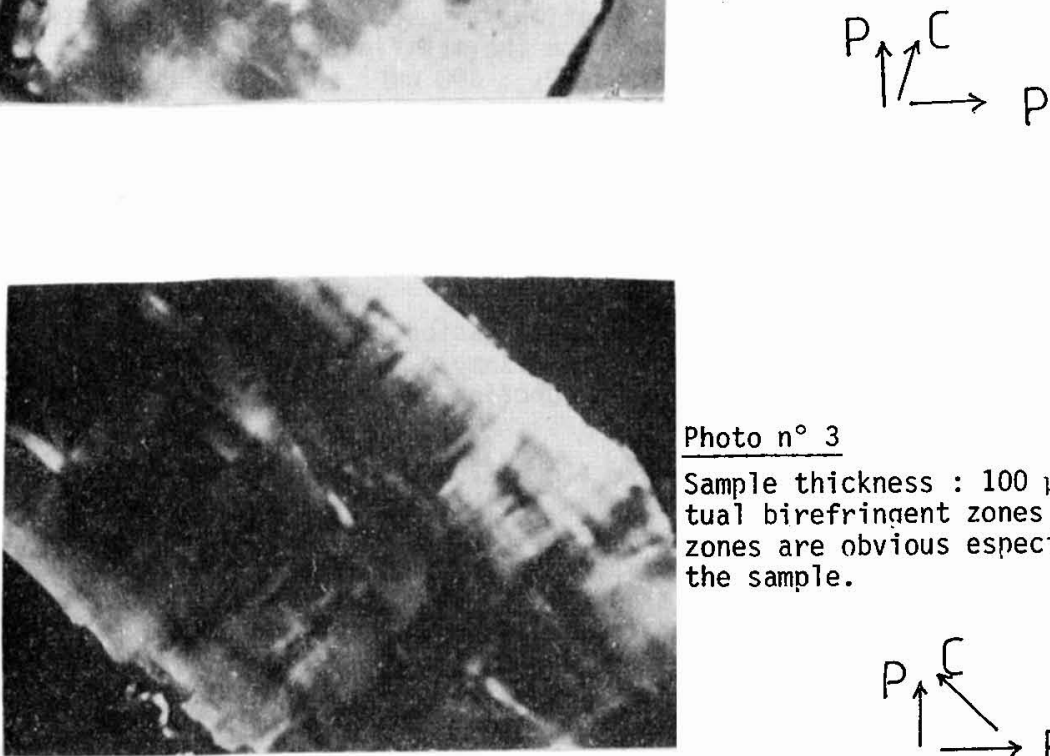

Photo $n^{\circ} 3$

Sample thickness : $100 \mu \mathrm{m}$. Some ponctual birefrincent zones appear. Spread zones are obvious especially alongside the sample.

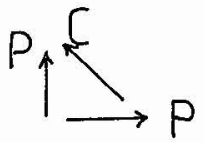




\section{Figure $n^{\circ} 1$}

Raman spectra of deformed and annealed silica glass.

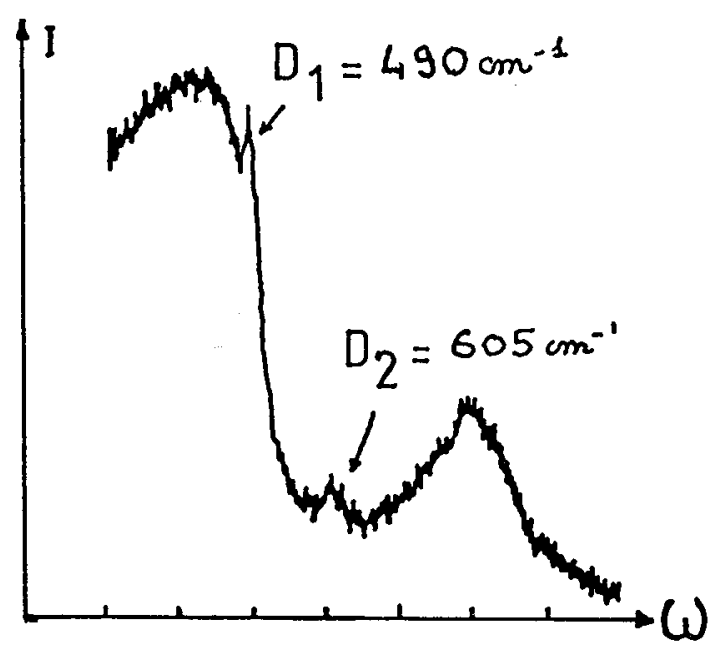
a) This sample has been deformed under 500 bars at $\mathrm{T}=1000^{\circ} \mathrm{C}$. (deformation amount $10 \%$ )

b) This sample was in the same furnace as the previous one but it has been just annealed at $T=1000^{\circ} \mathrm{C}$ for the deformation time.

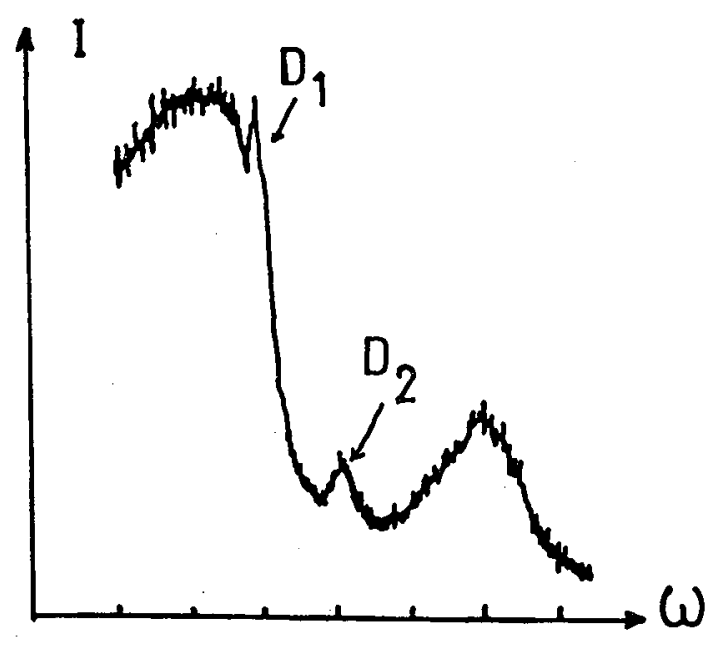


Two kinds of zones are obvious (photo $n^{\circ} 1$ ) : spread zones and small birefringent crosses (rough size : $100 \mu \mathrm{m}$ ). Moreover these crosses seem to be regularly arranged. To our knowledge, such heterogeneity in the low temperature deformation of a covalent glass has never been observed. The sample remains amorphous : the birefringent zones are not due to microcrystals. These zones must have a new kind of amorphous arrangement which is induced by the flow mechanism.

Since the $X$-Rays scattering intensity was the same for any silica glass sample (deformed or not), we tried Raman microspectroscopy. Silica glass has given rise to many experimental studies and interpretations of the Raman spectra (especially of the two sharp lines $D_{1}$ and $D_{2}$ ). The intensity of these lines is known to be sensitive to thermal history $15 \%$. Thus we have to be careful in our comparisons of the Spectra: a sample which has been deformed at a temperature $T$ is compared with an undeformed sample, annealed in the deformation conditions (same temperature and same time of annealing). The thin sections examined previously are now put in a Raman microprobe. A11 Raman spectra are obtained in the back scattering configuration (laser power : $600 \mathrm{~mW}$, wave length : $514,5 \mathrm{~mm}$ ).

There was no difference in the Raman spectra between samples which have been deformed or annealed at a temperature ahove $\mathrm{Tg}$ but differences are obvious for below $\mathrm{Tg}$ experiments. Figure $n^{\circ} 1$ shnws the Raman Spectra in this case. The broad features are not modified but the intensity of the sharp lines has changed. Comparina figures $n^{\circ} 1 a$ and $1 b$, we see that the deformation makes the line $D_{2}$ decrease. Any modification of the line $D_{1}$ is less evident.

When a deformed sample is annealed near the glass transition (figure $n^{\circ} 1 \mathrm{c}$ ), the line $D_{2}$ comes back to its previous intensity. Provided that we are able to interpret the Raman Spectra, such experiments give an important information about the deformation mechanism. Owing to the convincing interpretation given by Galeener $/ 3 /$, the decrease of the line $D_{2}$ can be interpreted as a modification of the number of threefold rings of tetrahedra. As there is about $1 \%$ threefold rings in silica glass, it is a very slight modification of the ring statistic. Thus we can think to a new approach of atomic transport in glass based on this experimental result : under stresses Si.0 atoms are transferred from a ring to another one.

\section{CONCLUDING REMARKS}

These experiments have given some new structurat knowledge on the deformation in silica glass,

Raman spectroscopy appears as a very keen technic in order to get some information concerning the ring statistic. We have yet some more investigations to do on deformed samples. Electron microscopy will be done on our sample to precise the local order of the birefringent zones.

\section{REFERENCES}

/1/ Pampillo C.A., Chen H.S., Mat. Sci. Eng., 13 (1974) 181.

/2/ Polk D.E., Turnbu11 D., Actat Met., 20 (1972) 493.

/3/ Galeener F.L., J. Non Cryst. Solids, 49 (1982) 53.

14/ Donnadieu P., Jaoul 0., Klêman M., to be published in Phit. Mag.

15/ Geissberger A.E., Galeener F.L., Phys. Rev. B28 (1983) 3266.

We are grateful to J. Laureyns (Laboratoire de Spectroscopie Infrarouge LASIR) for his help in the manipulation of the Raman microprobe MOLE. 